\title{
Viability and reconstitution of delta- endotoxins from Bacillus thuringiensis var. israelensis extracts after forty years of storage against Aedes aegypti (Diptera: Culicidae)
}

David Fernández-Chapa, Hugo Alberto Luna-Olvera, Jesica Ramirez-Villalobos, Guadalupe Rojas-Verde, Katiushka Arévalo-Niño and Luis Jesús Galán-Wong*

\begin{abstract}
Background: Bacillus thuringiensis subsp. israelensis (Bti) produces insecticidal endotoxins known as Cry and Cyt. Its efficiency and specificity make it the most widely used substance as a biopesticide for controlling disease from vector insects, such as mosquitoes, responsible for important human diseases such as malaria, filariasis, dengue, and yellow fevers. To date, it is proven difficult to develop a commercial product that has more than 2 years of shelf life, and there is little information on the viability of these commercial proteins under prolonged storage conditions.

Results: This study aimed to evaluate biological activity of reconstituted Bti endotoxins after 40 years of storage against the mosquito Aedes aegypti larvae. Five concentrations of Bti extracts were used for bioassays against 3rd and 4th instars of $A$. aegypti larvae. All reconstituted endotoxins from stored extracts showed a potency increase. The strain HD-500 from extract 3260 was the most effective insecticide $\left(L C_{50}=0.0014 \mathrm{mg} / \mathrm{l}\right)$, followed by $3756\left(L C_{50}=0.0037 \mathrm{mg} /\right.$ I). These strains were particularly notable, increasing their larvicidal potency one hundredfold and one thousandfold, respectively. Protein profiles in polyacrylamide gels revealed a greater presence of Cyt toxins compared to the stored Bti extracts, which maintained their activity at high concentrations.

Conclusion: The reconstituted Bti strains presented a great biological activity against $A$. aegypti larvae, specially extract 3260 (median lethal concentration $\left(L C_{50}\right)$ value $=0.0014 \mathrm{mg} / \mathrm{l}$ ). This considerable larvicidal activity after 40 years under storage was an encouraging signal for the development of future formulation strategies regarding their useful life. The stability of extracts of stored endotoxins produced by Bti decreased significantly, particularly Cyt1A protein, which is responsible for their synergistic activity.
\end{abstract}

Keywords: Bacillus thuringiensis var. israelensis, Shelf life extracts, Endotoxins, Aedes aegypti

\footnotetext{
* Correspondence: ljgw55@gmail.com

Instituto de Biotecnología, Facultad de Ciencias Biológicas, Universidad

Autónoma de Nuevo León, Pedro de Alba S/N, Ciudad Universitaria, San

Nicolás de los Garza, Nuevo León CP. 66451, México
}

\section{Springer Open}

(c) The Author(s). 2021 Open Access This article is licensed under a Creative Commons Attribution 4.0 International License, which permits use, sharing, adaptation, distribution and reproduction in any medium or format, as long as you give appropriate credit to the original author(s) and the source, provide a link to the Creative Commons licence, and indicate if changes were made. The images or other third party material in this article are included in the article's Creative Commons licence, unless indicated otherwise in a credit line to the material. If material is not included in the article's Creative Commons licence and your intended use is not permitted by statutory regulation or exceeds the permitted use, you will need to obtain permission directly from the copyright holder. To view a copy of this licence, visit http://creativecommons.org/licenses/by/4.0/. 


\section{Background}

Bacillus thuringiensis subsp. israelensis (Bti) is a ubiquitous gram-positive, rod-shaped bacterium first isolated in 1976 (Goldberg and Margalit 1977). During its sporulation phase, it produces at least 4 different crystal proteins, Cry (Cry4Aa, Cry4Ba, and Cry11Aa) and Cyt (Cyt1Aa) (Crickmore et al. 1998; Berry et al. 2002). These proteins are particularly toxic to different mosquito species and constitute two non-related families of delta-endotoxins.

The demand for bioinsecticides as a remedy for chemical insecticides is increasing, but as the world market expands, it is necessary to improve the long-term efficiency of active ingredients to improve formulations' shelf life as a pest management strategy. This directly involves public health and the increasing number of people affected around the world by mosquitoes, such as Aedes aegypti, Anopheles sp. and Culex sp., vectors of important human diseases such as malaria, filariasis, dengue, and yellow fevers, and cause of millions of deaths every year (Gad and Al-Dakhil 2018). Bti-based bioinsecticides are the most widely used larvicides in the world for mosquito control, mainly due to the synergistic combinations between Cry and Cyt dipteran specific toxins (Pérez et al. 2005; Cantón et al. 2011; Park et al. 2013). Each one of the Bti proteins had demonstrated different patterns of persistence (Cry $4>$ Cry $11>$ Cyt) in the environment (Tetreau et al. 2012). It is known that products based on natural molecules tend to be less stable than synthetic compounds; hence, shelf life of entomopathogen formulations is often low (Villaverde et al. 2014; Moustafa et al. 2018). Few studies have evaluated the persistence of the insecticidal activity of $B$. thuringiensis formulations under storage conditions, whereby the percentage loss of the formulated $B t$ products after a period of over 2 years $(24 \%)$ was higher than the permissible limit (16\%) demonstrating low shelf life (Moustafa et al. 2018). There are no reports indicating that the viability of Bti commercial products exceeds 2 years under ambient conditions. A recent study was undertaken to evaluate the persistence of $20 \mathrm{Bti}$ extracts stored for prolonged periods of time. All extracts presented biological activity at high concentrations against A. aegypti larvae, demonstrating the biological persistence of crystal proteins (Galán et al. 2017). The reconstitution and characterization of Bti toxins has never been evaluated after long storage periods, nor observed whether they have retained their genetic capacity and maintained the same biologic activity after reactivation.

Therefore, in order to improve performance of $B t$ formulations, shelf life, and viability strategies, the purpose of this research was to reconstitute and determine the viability of the toxic proteins of Bti after 40 years under storage conditions.

\section{Methods}

\section{Bacillus thuringiensis var. israelensis strains}

Five Bti fermentation extracts with the code: 3260, 3501, 3691, 3696, and 3756, respectively, were produced by coprecipitation lactose-acetone method by Dulmage et al. (1970) at the US Department of Agriculture, Agricultural Research Service (USDA-ARS) from the strains HD-500 and HD-567, chosen from the previous work of Galán et al. (2017). During the storage period, all extracts were stored in dark and dry conditions exclusively for this purpose at $25 \pm 3^{\circ} \mathrm{C}$ in sterile and hermetic bottles.

\section{Reconstitution of toxic complex: spore $\partial$-endotoxin}

For each Bti extract, $20 \mathrm{mg}$ of powder was dissolved and homogenized on a vortexer in Eppendorf tubes with 1 $\mathrm{ml}$ of sterile ionized water, reactivated in Petri dishes and incubated in BD Bioxon nutrient agar for $48 \mathrm{~h}$ at $30^{\circ} \mathrm{C}$. Subsequently, the colonies were inoculated into 50-ml flasks containing $10 \mathrm{ml}$ nutrient broth (NB, Difco) as a culture medium for $12 \mathrm{~h}$ at $30^{\circ} \mathrm{C}$ in an incubator shaker (New Brunswick Scientific Co., Inc., Edison, NJ) running at $150 \mathrm{rpm}$. Then, $1 \mathrm{ml}$ from each of the cultures in the mid-logarithmic growth phase was transferred into 500-ml Erlenmeyer flasks containing $100 \mathrm{ml}$ of the same medium for $72 \mathrm{~h}$ at $30^{\circ} \mathrm{C}$ in the same shaker running at $150 \mathrm{rpm}$ until $80 \%$ sporulation had been achieved and most of the spores and crystals had been released. The spore-crystal complex was then extracted using the lactose-acetone co-precipitation method (Dulmage et al. 1970).

\section{Aedes aegypti bioassays}

Toxicity against $A$. aegypti larvae was determined by multiple bioassays under laboratory conditions. The larvae of the 3rd and 4th instars of $A$. aegypti, used in these experiments, were obtained from the insectary of the Institute of Biotechnology of the School of Biology of the UANL. This mosquito colony has been permanently maintained under pathogen-free conditions at 28 to $30^{\circ} \mathrm{C}$, with $60-80 \%$ relative humidity and light/dark cycles of $12 \mathrm{~h}$. The larvae were fed daily on finely ground presterilized dog food (Pedigree brand).

For each Bti extract tested, 4 replicates per concentration were performed on 25 individuals of the 3 rd instar larvae, which contained $150 \mathrm{ml}$ of tap water with the bioinsecticide, according to the standard bioassay procedure described by the World Health Organization (2005). Five negative controls consisting of larvae exposed to tap water only were performed, and as a positive control (100\% mortality), a primary standard was prepared from VectoBac $3000 \mathrm{UTI} / \mathrm{mg}$ (Valent BioSciences Corp. Libertyville, IL). All bioassays were performed at room temperature $\left(25-28^{\circ} \mathrm{C}\right)$. Suspensions of each fermentation extract were prepared at $200 \mathrm{ppm}$ in 
Erlenmeyer flasks. Several dilutions were then made to obtain final concentrations of each treatment $(5,1,0.5$, $0.1,0.05,0.01,0.005$, and $0.001 \mathrm{mg} / \mathrm{l})$.

\section{Protein profile analysis}

The protein profiles of $B t$ spore-crystal toxins were analyzed by SDS-PAGE. A total of $1 \mathrm{mg}$ of crystal and spores from each Bti strain was solubilized in $100 \mu \mathrm{l}$ of Nanopure water. They were fractionated by protein buffer (2-mercaptoethanol 5\%, Tris-HCL $60 \mathrm{mM}$ pH 6.8, glycerol 25\%, SDS $2 \%$, bromophenol blue $0.1 \%$ ), heated $\left(95^{\circ} \mathrm{C}\right.$ for $5 \mathrm{~min}$ ), and then analyzed by sodium dodecyl sulfate $12 \%$ polyacrylamide gel electrophoresis (SDSPAGE). Finally, proteins were visualized by Coomassie blue staining (Green and Sambrook 2012).

\section{Statistical analysis}

Results were tabulated according to concentrations, considering the number of live and dead larvae with 4 replications per treatment, performed in triplicate at 24 and $48 \mathrm{~h}$. Values of $50 \%$ lethal concentration $\left(\mathrm{LC}_{50}\right)$ as well as confidence limits were obtained by probit analysis (Finney 1971) Repeated measures ANOVA and TukeyKramer post hoc measurements were performed to compare the means among the different extract treatments under different conditions, using the NCSS statistical software (2019).

\section{Results}

\section{Efficacy of stored and reconstituted Bti extracts against} Aedes aegypti

The Bti extracts generated under lactose-acetone coprecipitation methodology (Dulmage et al. 1970) and recovered after extensive storage period presented significant mortality during the first $24 \mathrm{~h}$, using 5 treatments at different concentrations $(0.1,0.05,0.01$, 0.005 , and $0.001 \mathrm{mg} / \mathrm{l})$. The mortality time of reconstituted Bti endotoxins from stored extracts on $A$. aegypti larvae is depicted in Table 1 . The reduction in larval population was observed each $12 \mathrm{~h}$, except in the control experiment. Extracts 3260 and 3756 demonstrated high mortality rates against $A$. aegypti larvae in the first hour of application, surpassing even the most commercial products, thus making them good candidates for development as a high yield bioinsecticides. This strong larvicidal activity is evidence of high spore viability and preservation of a strain's genetic capacities.

The results of these 5 reactivated strains tested in bioassays against $3 \mathrm{rd}$ and 4 th instars of $A$. aegypti larvae showed significant differences in the biological activity, compared with the stored extracts. As shown in Fig. 1, they presented toxic activity at the concentrations as low as 0.001 and $0.005 \mathrm{mg} / \mathrm{l}$, as in the case of the extracts
Table 1 Mortality response time from twenty-five Aedes aegypti larvae per concentration. Five different treatments were tested from Bacillus thuringiensis subsp. israelensis (Bti) reactivated extracts

\begin{tabular}{|c|c|c|c|c|c|c|}
\hline \multirow[t]{2}{*}{ Bti HD extracts } & \multirow{2}{*}{$\begin{array}{l}\text { Time } \\
\text { (h) }\end{array}$} & \multicolumn{5}{|c|}{ Dead larvae/concentration (mg/l) } \\
\hline & & 0.1 & 0.05 & 0.01 & 0.005 & 0.001 \\
\hline \multirow[t]{5}{*}{3260} & 1 & 25 & 25 & 12 & 1 & 0 \\
\hline & 12 & 25 & 25 & 25 & 15 & 4 \\
\hline & 24 & 25 & 25 & 25 & 24 & 9 \\
\hline & 36 & 25 & 25 & 25 & 25 & 12 \\
\hline & 48 & 25 & 25 & 25 & 25 & 14 \\
\hline \multirow[t]{5}{*}{3501} & 1 & 1 & 0 & 0 & 0 & 0 \\
\hline & 12 & 10 & 1 & 0 & 0 & 0 \\
\hline & 24 & 18 & 4 & 2 & 0 & 0 \\
\hline & 36 & 22 & 11 & 3 & 0 & 0 \\
\hline & 48 & 23 & 18 & 5 & 1 & 0 \\
\hline \multirow[t]{5}{*}{3691} & 1 & 0 & 0 & 0 & 0 & 0 \\
\hline & 12 & 8 & 3 & 0 & 0 & 0 \\
\hline & 24 & 17 & 5 & 0 & 0 & 0 \\
\hline & 36 & 22 & 9 & 0 & 0 & 0 \\
\hline & 48 & 22 & 13 & 1 & 0 & 0 \\
\hline \multirow[t]{5}{*}{3696} & 1 & 0 & 0 & 0 & 0 & 0 \\
\hline & 12 & 9 & 2 & 0 & 0 & 0 \\
\hline & 24 & 15 & 5 & 0 & 0 & 0 \\
\hline & 36 & 18 & 7 & 2 & 0 & 0 \\
\hline & 48 & 20 & 9 & 2 & 0 & 0 \\
\hline \multirow[t]{5}{*}{3756} & 1 & 25 & 8 & 2 & 0 & 0 \\
\hline & 12 & 25 & 20 & 24 & 13 & 0 \\
\hline & 24 & 25 & 25 & 25 & 20 & 0 \\
\hline & 36 & 25 & 25 & 25 & 23 & 1 \\
\hline & 48 & 25 & 25 & 25 & 24 & 3 \\
\hline \multirow[t]{5}{*}{ VectoBac $^{\mathrm{a}}$ (control) } & 1 & 8 & - & - & - & - \\
\hline & 12 & 13 & - & - & - & - \\
\hline & 24 & 18 & - & - & - & - \\
\hline & 36 & 25 & - & - & - & - \\
\hline & 48 & 25 & - & - & - & - \\
\hline
\end{tabular}

$\mathrm{a}_{3000 \mathrm{UTI} / \mathrm{mg}}$

3260 and 3756, respectively, which presented higher biological activity than the other reconstituted extracts tested after 40 years in storage.

Strain HD-567 from reconstituted extract 3260 killed $50 \%$ of mosquito larvae $\left(\mathrm{LC}_{50}\right)$ at $0.0014 \mathrm{mg} / \mathrm{l}$, much higher mortality rate than the standard Bti powder VectoBac $(0.01 \mathrm{mg} / \mathrm{l})$. Extract $3756\left(\mathrm{LC}_{50} 0.0038 \mathrm{mg} / \mathrm{l}\right)$ from strain HD-500 was the one which increased its toxicity than all reactivated samples, increasing its larvicidal potency one thousandfold (Fig. 2). 


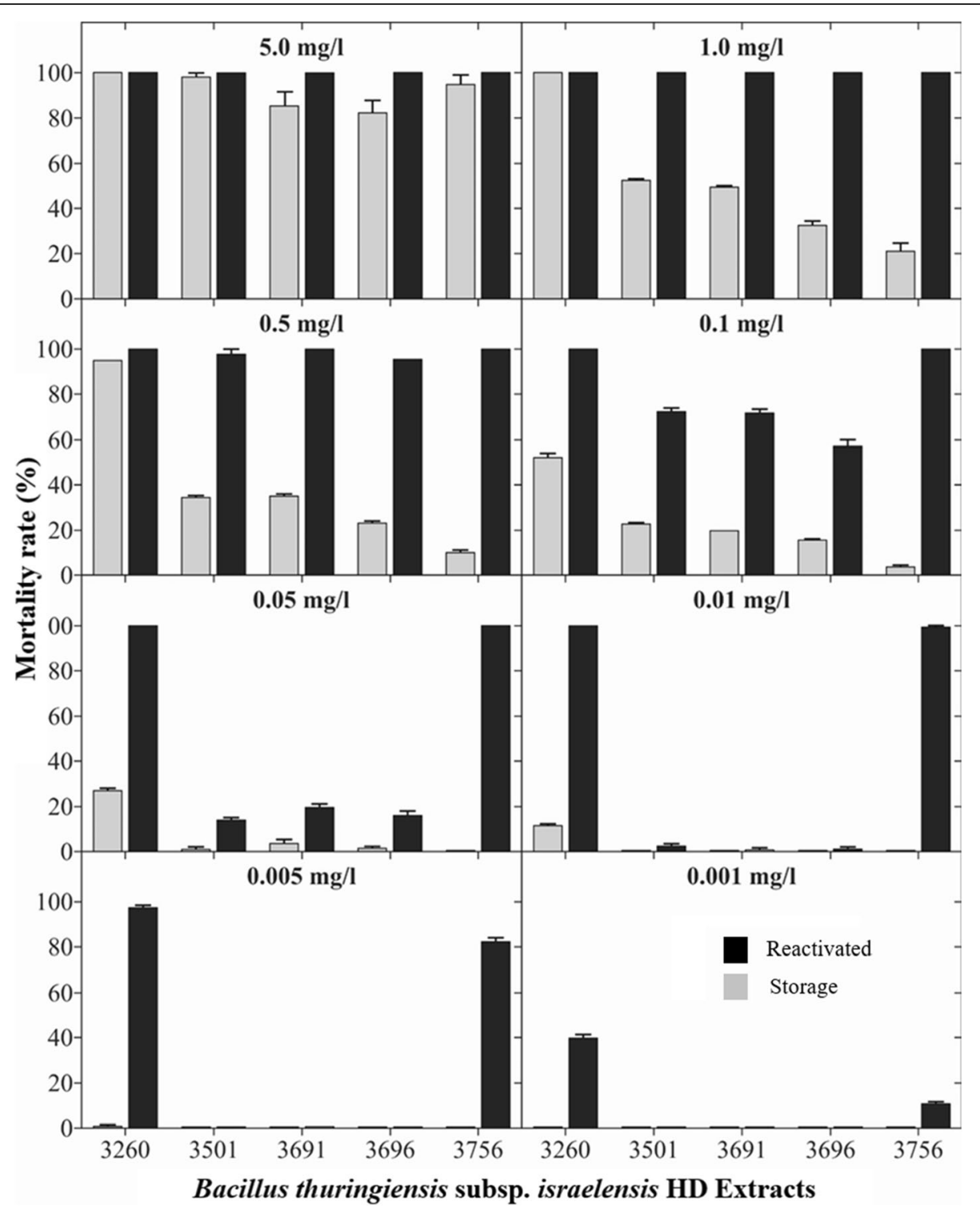

Fig. 1 Mortality percentage of Aedes aegypti larvae exposed to different HD extracts concentrations from Bacillus thuringiensis subsp. israelensis (Bti)

\section{Endotoxin analysis from Bti extracts}

SDS-PAGE analysis comparisons of the protein profiles between $\mathrm{HD}$ extracts (stored and reconstituted) and the known reference Bti-H14 (Zghal and Jaoua 2006) revealed that overall all Bti extracts showed patterns similar to BtiH14. However, the protein profile of reconstituted Bti extracts was strikingly different from that shown for those subjected to long periods of time (40 years). Both shared several protein bands ( $\geq 75 \%$ ), but reconstituted Bti extracts presented stronger bands, with molecular masses of approximately 70 and $100 \mathrm{kDa}$, respectively, but of particular interest was one band of approximately $28 \mathrm{kDa}$, the expected size for the synergic toxic protein Cyt1A (Fig. 3).

The $\mathrm{LC}_{50}$ of the extracts 3501, 3969, and 3691, ranged around $0.10 \mathrm{mg} / \mathrm{l}$, considerably enhanced than the stored ones, increased their potency tenfold, a product of active protein reconstitution. During evaluation of stored extracts, even at the concentrations of $5 \mathrm{mg} / \mathrm{l}$, their toxic activity for killing larvae continued to be unaltered as shown in Table 2. Negative control assays showed no mortality.

\section{Discussion}

After maintaining Bti extracts under storage for 40 years (the longest time studied up to the present) confirmed the long-term viability of Bti endotoxin proteins after isolation through lactose-acetone treatment after such long periods of time under storage. Conversely, the few reports on persistent toxicity in the field or under control indicate that these proteins rapidly lose their 


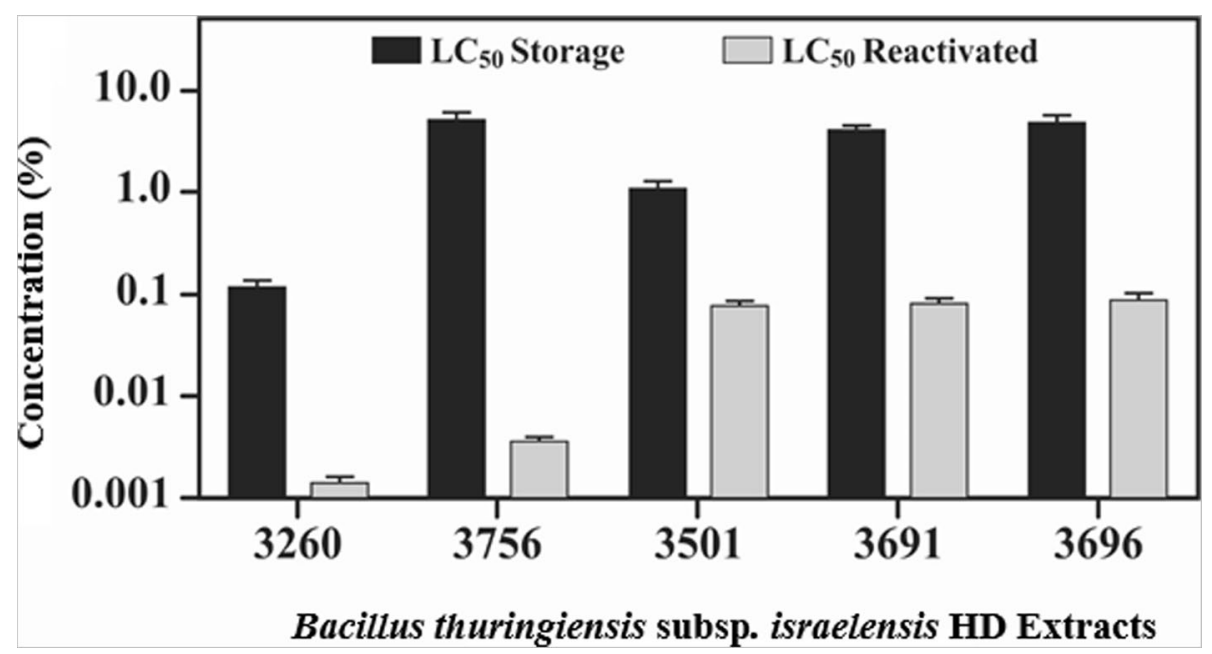

Fig. 2 Results of the probit analysis of the cumulative mortality obtained from experiments with A. aegypti larvae at $24 \mathrm{~h}$, comparing the median lethal concentration of both reactivated and stored Bacillus thuringiensis subsp. israelensis (Bti) fermentation

insecticidal properties due to different causes. Among the environmental factors that negatively affect the persistence of toxicity are temperature, solar radiation, $\mathrm{pH}$, organic matter, and solubilization (Manonmani et al. 2008; Hung et al. 2016). There are very few studies of the shelf life persistence of $B t$ endotoxins and commercial formulations. As natural products, their high biodegradable properties are well-known. Therefore, these imported products tend to have little efficacy under local and environmental conditions (Prior 1989). The continuous larvicidal activity of the stored extracts may be due to various factors, from its production to its conservation, such as keeping them in hermetically sealed vials, in order to avoid moisture absorption since this material was found to be highly hygroscopic (Manonmani et al. 2008). Likewise, the adsorption of the spore-crystal complex in the lactose particles collected during the production of the fermentation extract may have maintained the protein's conformational stability. Now it is known that binding to particles favors the protection of cells against damage and reduces their susceptibility to bacterial contamination and degradation, keeping them

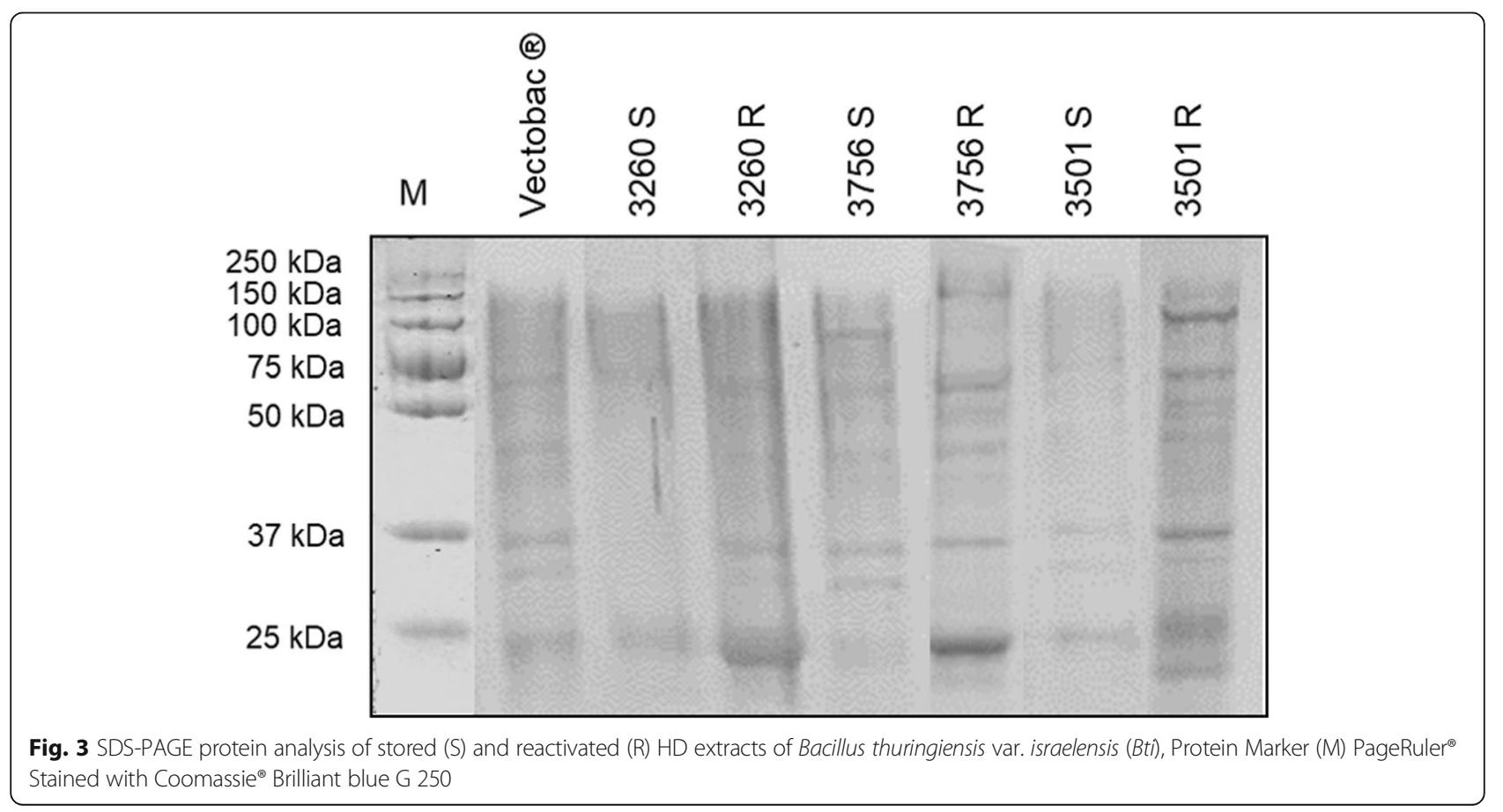


Table 2 Concentration mortality response of Aedes aegypti 3rd instar larvae to Bacillus thuringiensis subsp. israelensis (Bti) reactivated strain extracts (RE) and stored extracts (SE)

\begin{tabular}{|c|c|c|c|c|c|}
\hline \multirow{2}{*}{$\begin{array}{l}\text { Bti } \\
\text { strains }\end{array}$} & \multirow{2}{*}{$\begin{array}{l}\mathrm{LC}_{50}(\mathrm{mg} / \mathrm{l}) 24 \\
\mathrm{~h}(\mathrm{RE})\end{array}$} & \multicolumn{2}{|c|}{ Confidence interval 95\% } & \multirow{2}{*}{$\begin{array}{l}\mathrm{LC}_{50}(\mathrm{mg} / \\
\mathrm{l}) 24 \mathrm{~h} \\
\text { (SE) }\end{array}$} & \multirow{2}{*}{$\begin{array}{l}\text { Relative } \\
\text { toxicity } \\
\text { of SE }\end{array}$} \\
\hline & & Lower & Higher & & \\
\hline 3260 & $0.0014 \pm 0.0001$ & 0.0012 & 0.0016 & $0.12 \pm 0.01$ & 1.16 \\
\hline 3756 & $0.0037 \pm 0.0002$ & 0.0035 & 0.0039 & $5.52 \pm 0.19$ & 0.06 \\
\hline 3501 & $0.0852 \pm 0.0026$ & 0.0764 & 0.0940 & $1.16 \pm 0.03$ & 7.34 \\
\hline 3691 & $0.0840 \pm 0.0029$ & 0.0757 & 0.0923 & $4.21 \pm 0.15$ & 1.99 \\
\hline 3696 & $0.0924 \pm 0.0053$ & 0.0813 & 0.1035 & $5.2 \pm 0.11$ & 1.77 \\
\hline
\end{tabular}

biologically active (Vettori et al. 2003; Prabakaran and Hoti 2008). These findings indicated that the recovery method for spore-crystal complex by means of lactoseacetone coprecipitation, coupled with specific conditions of humidity, temperature, and light, can extend the shelf life of Bti extracts and retain the biological activity of endotoxins for decades.

The results obtained in the protein analysis are consistent with the differential persistence of the biological activity observed on the bioassays, under laboratory conditions against $A$. aegypti larvae. According to different studies, it is suggested that the larger the protein size, the longest it persists: Cry4 $(130 \mathrm{kDa})>\mathrm{Cry} 11(70 \mathrm{kDa})>$ Cyt (28 kDa) (Tetreau et al. 2012 and Ben 2014). In this study, it was clear that all Bti extracts tested had a high storage stability, in contrast with findings of different studies reporting poor protein stability of endotoxins under storage periods, in which shelf life was often low and the viability of products did not exceed 2 years under ambient conditions (Moustafa et al. 2018).

The toxic potency of Bti proteins lies in their synergistic activity attributed to complex interactions among the 4 main endotoxins: Cry4A, Cry4B, Cry11Aa, and Cyt1 (Pérez et al. 2005; Pérez et al. 2007; Cantón et al. 2011; Elleuch et al. 2015). The larvicidal activity of each of the 4 Cry's was greater than those of Cyt, but the high activity of the entire crystal was a product of synergies between them (Pérez et al. 2007; Ben 2014). The low rates of Cyt1Aa toxin observed in the protein profile analysis (Fig. 3) might have affected the biological activity of the stored extracts due to the unique characteristic of Cyt1Aa, serving as an additional receptor for Bti Cry proteins. Cyt1A improves the activity of Cry toxins, enabling them to function as membrane-bound receptors, hence improving their binding to epithelial microvilli in the intestine of the $A$. aegypti insect, and facilitating the formation of pre-pore oligomeric structures, thus synergizing their toxicity (Cantón et al. 2011; Ben 2014; Torres et al. 2018). The loss of Cyt biological activity in stored extracts may be due to the latent presence of proteases, as well as the constant temperature $\left(25^{\circ} \mathrm{C}\right)$ for long periods of time. All this can produce conformational changes in its structure (Hung et al. 2016), thus hinder toxic activity. However, there are some reports highlighting UV light and sunlight as a primary degradation pathway (Hung et al. 2016; Moustafa et al. 2018). Further research is needed to understand the role that this disaccharide could have in moderately conserving the activity and viability of the larvicidal proteins. The data obtained encourage developing future formulation strategies regarding their useful life and continued biological activity for long periods under storage conditions to significantly increase yield.

\section{Conclusion}

The stored extracts of Bti maintained their viability and genetic capacities after 40 years under storage; nevertheless, the synergistic protein Cyt1A was the most susceptible, having a high rate of decline. The recovery method for spore-crystal complex by means of lactose-acetone coprecipitation, maintained under specific storage conditions, including humidity, temperature, and light, held endotoxins stable for many years.

\section{Abbreviation \\ Bti: Bacillus thuringiensis israelensis}

\section{Acknowledgements}

We thank the National Council of Science and Technology (CONACYT) for the grant to carry out this work. To the Institute of Biotechnology and the Universidad Autónoma de Nuevo León, México for providing the infrastructure for the development of this project.

\section{Authors' contributions}

DFC conceived and designed the methodology and experiments, carried out the maintenance of the insectary for the mosquito breeding, performed all the experimental work, analyzed and interpreted the data, and wrote the manuscript. HALO contributed analysis tools and authored and reviewed drafts of the paper. JRV made substantial contributions to the conception of experiments regarding $A$. aegypti bioassays and authored drafts of the paper. GRV contributed reagents and material analysis and authored drafts of the paper. KAN contributed reagents and material analysis and authored drafts of the paper. LGW performed the idea of this article, analyzed the data, contributed reagents/materials/analysis tools, and authored or reviewed drafts of the paper. All authors have approved the submitted version and agreed to be personally accountable for the author's own contributions and the accuracy or integrity of any part of the work.

\section{Funding}

This work was supported by Grant No. 707437 from the National Council for Science and Technology, Mexico (CONACYT), and from the Universidad Autónoma de Nuevo León, México. David Daniel Fernández Chapa was the 
recipient of a fellowship from CONACYT, México. There was no additional external funding received for this study. The funders had no role in study design, data collection and analysis, decision to publish, or preparation of the manuscript.

\section{Availability of data and materials}

No supplemental files were produced for this publication, due to the processing of raw data through statistical analysis.

\section{Ethics approval and consent to participate}

Maintenance and protection of mosquitoes and larvae were performed under the indications of the "Guide for the breeding and maintenance of colonies of Aedes aegypti (Diptera: Culicidae) in insectary conditions" according with the Undersecretary of prevention and health promotion, as well as the Official Mexican Standard NOM-032-SSA2-2014, and performed in BSL-2 laboratory in the Biotechnology Institute, FCB, UANL.

\section{Consent for publication}

Not applicable

\section{Competing interests}

The authors declare that this work is a product of original research unrelated to any conflict of interest either economic or otherwise that could have influenced the results and has not previously been sent to any instance to be partially or completely published in any language.

Received: 16 September 2020 Accepted: 12 February 2021

Published online: 03 March 2021

\section{References}

Ben DE (2014) Bacillus thuringiensis subsp. israelensis and its dipteran-specific toxins. Toxins 6:1222-1243. https://doi.org/10.3390/toxins6041222

Berry C, O'Neil S, Ben DE (2002) Complete sequence and organization of pBtoxis, the toxin-coding plasmid of Bacillus thuringiensis subsp. israelensis. Appl Environ Microbiol 68:5082-5095. https://doi.org/10.1128/AEM.68.10.50825095.2002

Cantón PE, Reyes EZ, De Escudero IR, Bravo A, Soberón M (2011) Binding of Bacillus thuringiensis subsp. israelensis Cry4Ba to Cyt1 Aa has an important role in synergism. Peptides 32:595-600. https://doi.org/10.1016/j.peptides.2010.06. 005

Crickmore N, Zeigler DR, Feitelson J, Schnepf E, Van Rie J, Lereclus D, Baum J, Dean DH (1998) Revision of the nomenclature for the Bacillus thuringiensis pesticidal crystal proteins. Microbiol Mol Biol Rev 62:807-813. https://doi. org/10.1128/MMBR.62.3.807-813.1998

Dulmage HT, Correa JA, Martinez AJ (1970) Coprecipitation with lactose as a means of recovering the spore-crystal complex of Bacillus thuringiensis. J Invertebr Pathol 15:15-20. https://doi.org/10.1016/0022-2011(70)90093-5

Elleuch J, Jaoua S, Darriet F, Chandre F, Tounsi S, Zghal RZ (2015) Cry4Ba and Cyt1Aa proteins from Bacillus thuringiensis israelensis: interactions and toxicity mechanism against Aedes aegypti. Toxicon 104:83-90. https://doi.org/10.101 6/j.toxicon.2015.07.337

Finney DJ (1971) Probit analysis. Cambridge University Press, Cambridge

Gad A, Al-Dakhil A (2018) Efficacy of Bacillus thuringiensis israelensis (Bti) and four plant extracts on the mortality and development of Culex quinquefasciatus Say (Diptera: Cullicidae). Egypt J Biol Pest Control 28:62. https://doi.org/10.11 86/s41938-018-0066-8

Galán WL, Gamiño HR, Fernández CD, García DG, De La Garza RM, Guajardo BC, Luna $\mathrm{OH}$ (2017) Persistence of toxic activity of fermentation extracts from Bacillus thuringiensis var. israelensis after more than three decades of storage. Int J Microbiol. https://doi.org/10.1155/2017/5402748

Goldberg $\sqcup$, Margalit J (1977) A bacterial spore demonstrating rapid larvicidal activity against Anopheles sergentii, Uranotaenia unguiculata, Culex univitattus, Aedes aegypti, and Culex pipiens. Mosq News 37:355-358

Green MR, Sambrook J (2012) Molecular cloning: a laboratory manual. Cold Spring Harbor Laboratory Press, Cold Spring Harbor, p 1609

Hung TP, Truong LV, Binh ND, Frutos R, Quiquampoix H, Staunton S (2016) Persistence of detectable insecticidal proteins from Bacillus thuringiensis (Cry) and toxicity after adsorption on contrasting soils. Environ Pollut 208:318-325. https://doi.org/10.1016/j.envpol.2015.09.046

Manonmani AM, Prabakaran G, Hoti SL (2008) Retention of mosquito larvicidal activity of lyophilized cells and WDP formulation of Bacillus thuringiensis var. israelensis on long-term storage. Acta Trop 105:170-175. https://doi.org/10.1 016/.jactatropica.2007.11.002

Moustafa AM, Saleh MA, Ateya IR, Kandil MA (2018) Influence of some environmental conditions on stability and activity of Bacillus thuringiensis formulations against the cotton leaf worm, Spodoptera littoralis (Boisd.) (Lepidoptera: Noctuidae). Egypt J Biol Pest Control 28:61. https://doi.org/1 0.1186/s41938-018-0064-x

Park HW, Pino BC, Kozervanich CS, Hafkenscheid EA, Oliverio RM, Federici BA, Bideshi DK (2013) Cyt1Aa from Bacillus thuringiensis subsp. israelensis enhances mosquitocidal activity of $B$. thuringiensis subsp. kurstaki HD-1 against Aedes aegypti but not Culex quinquefasciatus. J Microbiol Biotechnol 23:88-91. https://doi.org/10.4014/jmb.1207.07061

Pérez C, Fernandez LE, Sun J, Folch JL, Gill SS, Soberón M, Bravo A (2005) Bacillus thuringiensis subsp. israelensis Cyt1Aa synergizes Cry11Aa toxin by functioning as a membrane-bound receptor. Proc Natl Acad Sci U S A 102: 18303-18308. https://doi.org/10.1073/pnas.0505494102

Pérez C, Muñoz GC, Portugal LC, Sánchez J, Gill SS, Soberón M, Bravo A (2007) Bacillus thuringiensis ssp. israelensis Cyt1 Aa enhances activity of Cry $11 \mathrm{Aa}$ toxin by facilitating the formation of a pre-pore oligomeric structure. Cell Microbiol 9:2931-2937. https://doi.org/10.1111/j.1462-5822.2007.01007.x

Prabakaran G, Hoti SL (2008) Immobilization of alginate-encapsulated Bacillus thuringiensis var. israelensis containing different multivalent counterions for mosquito control. Curr Microbiol 57:111-114. https://doi.org/10.1007/s00284008-9159-z

Prior C (1989) Biological pesticides for low external-input agriculture. Biocont. News Inform 10:17-22

Tetreau G, Alessi M, Veyrenc S, Périgon S, David JP, Reynaud S, Després L (2012) Fate of Bacillus thuringiensis subsp. israelensis in the field: evidence for spore recycling and differential persistence of toxins in leaf litter. Appl Environ Microbiol 78:8362-8367. https://doi.org/10.1128/AEM.02088-12

Torres QC, Gómez I, Pacheco S, Sánchez J, Flores H, Osuna J, Mendoza G, Soberón M, Bravo A (2018) Engineering Bacillus thuringiensis Cyt1Aa toxin specificity from dipteran to lepidopteran toxicity. Sci Rep 8:4989. https://doi. org/10.1038/s41598-018-22740-9

Vettori C, Paffetti D, Saxena D, Stotzky G (2003) Persistence of toxins and cells of Bacillus thuringiensis subsp. kurstaki introduced in sprays to Sardinia soils. Soil Biol Biochem 35:1635-1642. https://doi.org/10.1016/.soilbio.2003.08.009

Villaverde JJ, Sevilla MB, Sandín EP, López GC, Alonso JL (2014) Biopesticides in the framework of the European Pesticide Regulation (EC) No. 1107/2009. Pest Manag Sci 70:2-5. https://doi.org/10.1002/ps.3663

World Health Organization (2005) Guidelines for laboratory and field testing of mosquito larvicides. WHO/CDS/WHOPES/GCDPP/2005.13: World Health Organization. p. 39. https://apps.who.int/iris/handle/10665/6910.

Zghal R, Jaoua S (2006) Evidence of DNA rearrangements in the 128-kilobase pBtoxis plasmid of Bacillus thuringiensis israelensis. Mol Biotechnol 33:191198. https://doi.org/10.1385/MB:33:3:191

\section{Publisher's Note}

Springer Nature remains neutral with regard to jurisdictional claims in published maps and institutional affiliations.

\section{Submit your manuscript to a SpringerOpen ${ }^{\circ}$ journal and benefit from:}

- Convenient online submission

- Rigorous peer review

- Open access: articles freely available online

- High visibility within the field

- Retaining the copyright to your article

Submit your next manuscript at $\boldsymbol{\nabla}$ springeropen.com 